\title{
PREVALENCE OF PARACOCCIDIOIDOMYCOSIS INFECTION BY INTRADERMAL REACTION IN RURAL AREAS IN ALFENAS, MINAS GERAIS, BRAZIL
}

Evandro Monteiro de Sá MAGALHÃES(1), Carla de Fátima RIBEIRO(1), Carla Silva DÂMASO(1), Luiz Felipe Leomil COELHO(1), Roberta Ribeiro SILVA(2), Eric Batista FERREIRA(3), Maria Rita RODRIGUES(4), Zoilo Pires de CAMARGO(5), Tânia Regina Grão VELLOSO(6) \& Luiz Cosme Cotta MALAQUIAS(1)

\begin{abstract}
SUMMARY
This study aimed to estimate the prevalence of paracoccidioidal infection by intradermal reaction (Delayed-Type Hypersensitivity, DTH) to Paracoccidioides brasiliensis in rural areas in Alfenas, Southern Minas Gerais (MG) State, Brazil, and to assess risk factors (gender, occupation, age, alcohol intake and smoking) associated with infection. We conducted a population-based cross-sectional study using intradermal tests with gp 43 paracoccidioidin in 542 participants, who were previously contacted by local health agents and so spontaneously attended the test. Participants underwent an interview by filling out a registration form with epidemiological data and were tested with an intradermal administration of $0.1 \mathrm{~mL}$ of paracoccidioidin in the left forearm. The test was read 48 hours after injection and was considered positive if induration was greater than or equal to $5 \mathrm{~mm}$. Out of 542 participants, $46.67 \%$ were positive to the skin test. Prevalence increased in accordance with an increase of age. There was statistical significance only for males. Occupation, alcohol intake and smoking habits were not significantly associated with the risk of paracoccidioidomycosis infection. There is relevance of paracoccidioidomycosis infection in such rural areas, which suggests that further epidemiological and clinical studies on this mycosis should be done in the southern part of Minas Gerais State.
\end{abstract}

KEYWORDS: Paracoccidioidomycosis; Epidemiology; Health surveys; Intradermal tests.

\section{INTRODUCTION}

Paracoccidioidomycosis is a systemic mycosis, endemic and limited to Latin America. It is caused by the dimorphic species of fungus Paracoccidioides brasiliensis or Paracoccidioides lutzii which can exist as a mycelial stage and yeast ${ }^{26,36}$. The mycelial form is found in nature at temperatures between $18{ }^{\circ} \mathrm{C}$ and $25^{\circ} \mathrm{C}$ and produces spores or yeast-like conidia which may cause infections. Spores inhaled by susceptible hosts are converted into yeast in the tissues. By inhalation spores target the lungs and later on reach any systemic structure through the lymphatic or the blood stream, especially affecting skin, mucous membranes, lymphatic tissue and adrenal glands ${ }^{13,33}$.

$P$. brasiliensis, or $P$. lutzii, lives in argillaceous or sandy soil with adequate humidity. This fact points out the possibility of saprophytic life in soil, rich in organic matter, humid and protected against sunlight ${ }^{27}$.

Paracoccidioidomycosis distribution is heterogeneous showing high and low endemicity in different areas, in accordance with the climate and the agricultural conditions in the region. In Brazil, which is responsible for more than $80 \%$ of paracoccidioidomycosis cases in the world, asymptomatic infection is revealed by a cutaneous (Delayed-Type
Hypersensitivity) test using the antigen paracoccidioidin. This disease has higher prevalence in the Southeast, South and Central West regions ${ }^{20}$. It is believed that about $10 \%$ of the population may have been infected by the fungus, which represents a more impressive percentage than that related to other neglected diseases, e.g., schistomiasis and leishmaniasis ${ }^{14,20}$. There are also reports of cases in non endemic areas, related to people who had lived in or visited Latin America before the beginning of signs and symptoms of the disease. Under this condition paracoccidioidomycosis is considered a traveler's disease ${ }^{18,25}$.

The disease is mainly found among men who work in rural areas and it affects them between the ages of 30 to 50 years old when they are supposed to produce at their most productive age. For this reason, this disease has an important impact on the production chain and on public health ${ }^{2,3,19}$. Recently, it was included among the neglected diseases, that have a significant impact on public health and that are not sufficiently quantified due to the lack of available information, that paracoccidioidomycosis is not a disease of compulsory notification $^{10,19}$.

With this in mind, the goal of this study is to quantify the prevalence of people prone to P. brasiliensis in rural areas, in Alfenas - Southern

List of Abbreviations and Acronyms: IDR: intradermal reaction; CI: Confidence Interval

(1) Instituto de Ciências Biomédicas, Universidade Federal de Alfenas, MG, Brazil.

(2) Faculdade de Nutrição, Universidade Federal de Alfenas, MG, Brazil.

(3) Instituto de Ciências Exatas, Universidade Federal de Alfenas, MG, Brazil.

(4) Faculdade de Ciências Farmacêuticas, Universidade Federal de Alfenas, MG, Brazil.

(5) Departamento de Biologia Celular, Universidade Federal do Estado de São Paulo, SP, Brazil

(6) Departamento de Clínica Odontológica, Universidade Federal do Espírito Santo, ES, Brazil.

Correspondence to: Luiz Cosme Cotta Malaquias, Phone: + 55.35.3299-1305, Fax: +55.35.3299-1063. E-mail: luizcosme@ hotmail.com 


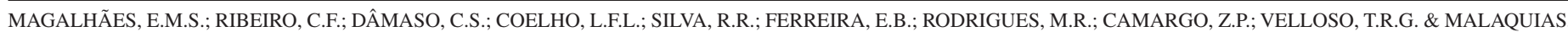
L.C.C. - Prevalence of paracoccidioidomycosis infection by intradermal reaction in rural areas in Alfenas, Minas Gerais, Brazil. Rev. Inst. Med. Trop. Sao Paulo, 56(4): 281-5, 2014.

MG, as well as to evaluate the influence of age, gender, alcohol intake, smoking and occupation associated with infection.

\section{MATERIALS AND METHODS}

Population studied: This study was carried out in the rural area, in Alfenas-MG, Brazil, from May to December 2009. The selected population to be studied consisted of 542 people, who lived in rural area. The selection was carried out on spontaneous demand. The participants were previously contacted by health agents. On the scheduled day, participants in the study (male and female, over 10 years old) were submitted to an interview, filling out a registration form, which presented epidemiologic data. Pregnant women were excluded. The written informed consent was obtained from each participant, taking into consideration the resolutions of the Brazilian National Health Council No. 196/1996 and 347/2005.

Intradermal tests The antigen used in the present work for the intradermal test was the exoantigen of $P$. brasiliensis (strain B-339), rich of gp43 (minimum concentration of 70\%) and was referred to as gp43 paracoccidioidin. The purified glycoprotein of $43 \mathrm{kD}$ from $P$. brasiliensis (gp43) was tested as paracoccidioidin, in DTH tests, in both experimental animals and patients with paracoccidioidomycosis, and compared with the traditional polysaccharide Fava Netto antigen.

The use of gp43 as paracoccidioidin in humans showed that this molecule can be used to evaluate the DTH response in patients with PCM. They found that patients who were responsive to $P$. brasiliensis antigen, $92.3 \%$ reacted against gp43 and 53.8\% reacted against Fava Netto antigen. Gp43 skin test responses were significantly higher than those obtained with Fava Netto antigen, demonstrating the efficacy of this preparation ${ }^{30}$.

The intradermal reaction tests were done by injecting $0.1 \mathrm{~mL}$ of exoantigen in the left forearm and readings of possible intradermal reaction were taken 48 hours after the injection. Induration equal to $5 \mathrm{~mm}$ or over was interpreted as a positive result.

Clinical, radiological and serological evaluation: Blood samples were taken, in order to perform hemogram and double agar gel immune diffusion tests. All IDR positive individuals were submitted to chest $\mathrm{x}$-rays and a medical examination (one examining doctor) to evaluate and exclude possible clinical disease in activity and/or sequelae.

Statistical tests: The data were submitted to statistical analysis by means of software $\mathrm{R}^{24}$. Analysis of frequency distribution of the main variables was performed, in order to characterize the population of the present study. The existence of association among the qualitative variables was evaluated by the chi-square test and the level of significance was $5 \%$. The logistic regression analysis was performed to confirm and inform the odds ratio, in relation to the factors that were significant, expressing the protectoral or potentializing effect on the studied disease.

\section{RESULTS}

A total of 557 intradermal reaction tests were performed but 15 individuals did not return for the results and were excluded from the research. Of the remaining 542 studied individuals, positive reaction to intradermal injection of paracoccidioidin was observed in $46.67 \%$ (Confidence Interval 95\% 0.42 to 0.51 ) of participants, which corresponds to 253 individuals. Of the individuals tested, 270 (49.82\%) belonged to the male gender and $272(50.18 \%)$ to the female gender. The age varied from 11 to 86 years old and the average age was 43 years. In relation to occupation, most participants reported regular activity in rural areas $(53.50 \%)$ revealing major exposure to $P$. brasiliensis. In relation to habits, $29.33 \%$ were addicted to smoking and $20.67 \%$ to alcohol (Table 1 ). None of the participants assessed presented clinical signs, radiological and serological findings indicative of disease activity. Table 2 shows the distribution of the intradermal reaction adjusted for age, gender, occupation, tobacco and alcohol use. Among subjects with positive IDR, $56.30 \%$ were men (Confidence Interval $95 \% 0.50$ to 0.62 ) and $37.13 \%$ women (Confidence Interval $95 \%$ to 0.43$)(p<0.001)$. The prevalence rate of sensitization grew progressively, in accordance with increasing age. From 11 to 29 years old, the prevalence rate was $35.37 \%$; from 30 to 49 , it was $49.56 \%(p<0.01)$. Over 50 years old, the rate was $52.66 \%$ $(p<0.01)$, being the highest one.

Table 1

Frequency distribution of intradermal test, gender, occupation, smoking and alcohol intake of the residents of an endemic area for paracoccidioidomycosis in 2009 in Alfenas, MG, Brazil

\begin{tabular}{|c|c|c|c|}
\hline Variants & & $\begin{array}{l}\text { Number of } \\
\text { individuals }\end{array}$ & $\%$ \\
\hline \multicolumn{4}{|l|}{ *IDR } \\
\hline & Negative & 289 & 53.33 \\
\hline & Positive & 253 & 46.67 \\
\hline & Total & 542 & 100.0 \\
\hline \multicolumn{4}{|l|}{ Gender } \\
\hline & Male & 270 & 49.82 \\
\hline & Female & 272 & 50.18 \\
\hline & Total & 542 & 100.0 \\
\hline \multicolumn{4}{|c|}{ Occupation } \\
\hline & Farm work & 290 & 53.50 \\
\hline & Others & 252 & 46.50 \\
\hline & Total & 542 & 100.0 \\
\hline \multicolumn{4}{|l|}{ Smoking } \\
\hline & Yes & 159 & 29.33 \\
\hline & No & 383 & 70.67 \\
\hline & Total & 542 & 100.0 \\
\hline \multicolumn{4}{|c|}{ Alcohol intake } \\
\hline & Yes & 112 & 20.67 \\
\hline & No & 430 & 79.33 \\
\hline & Total & 542 & 100.0 \\
\hline
\end{tabular}

*IDR = Intradermal reaction.

In relation to occupation (work in farming), $48.28 \%$ were positive to the IDR test. People addicted to tobacco were $52.2 \%$ positive; people addicted to alcohol were $55.36 \%$ positive. On the other hand, there was no statistical significant association between positive intradermal reaction (sensitization) and professional activity and a smoking habit $(p>0.05)$. However, addiction to alcohol revealed an influence to the level of positive 


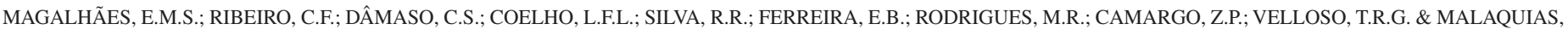
L.C.C. - Prevalence of paracoccidioidomycosis infection by intradermal reaction in rural areas in Alfenas, Minas Gerais, Brazil. Rev. Inst. Med. Trop. Sao Paulo, 56(4): $281-5,2014$.

Table 2

Intradermal results distributed by gender, profession, age range, smoking and alcoholism variants

\begin{tabular}{|c|c|c|c|c|c|c|c|c|}
\hline \multirow{3}{*}{ Variants } & & \multicolumn{6}{|c|}{ Intradermal reaction } & \multirow{3}{*}{$p$-value* } \\
\hline & & \multicolumn{2}{|c|}{ Positive } & \multicolumn{2}{|c|}{ Negative } & \multicolumn{2}{|c|}{ Total } & \\
\hline & & $* * * N(253)$ & $\%$ & $\mathrm{~N}(289)$ & $\%$ & $\mathrm{~N}(542)$ & $\%$ & \\
\hline \multirow{3}{*}{ Age range } & $11-29$ & 52 & 35.37 & 95 & 64.63 & 147 & 27.12 & \multirow{3}{*}{0.004674} \\
\hline & $30-49$ & 112 & 49.56 & 114 & 50.44 & 226 & 41.70 & \\
\hline & $>50$ & 89 & 52.66 & 80 & 47.34 & 169 & 31.18 & \\
\hline \multirow{2}{*}{ Gender } & Female & 101 & 37.13 & 171 & 62.87 & 272 & 50.18 & \multirow{2}{*}{0.00001} \\
\hline & Male & 152 & 56.30 & 118 & 43.70 & 270 & 49.82 & \\
\hline \multirow{2}{*}{ Occupation } & Farm work* & 140 & 48.28 & 150 & 51.72 & 290 & 53.51 & \multirow{2}{*}{0.4758} \\
\hline & Nonfarm work & 113 & 44.84 & 139 & 55.16 & 252 & 46.49 & \\
\hline \multirow{2}{*}{ Smoking } & Yes** & 83 & 52.20 & 76 & 47.80 & 159 & 29.34 & \multirow{2}{*}{0.1174} \\
\hline & No & 170 & 44.39 & 213 & 55.61 & 407 & 70.66 & \\
\hline \multirow{2}{*}{ Alcohol intake } & Yes** & 62 & 55.36 & 50 & 44.64 & 112 & 20.66 & \multirow{2}{*}{0.04994} \\
\hline & No & 191 & 44.42 & 239 & 55.58 & 430 & 79.33 & \\
\hline
\end{tabular}

$*$ It refers to chi-square test $(5 \%$ of significance). $* *$ This group contains the remaining individuals and the formers. $* * * \mathrm{~N}=$ number of individuals.

Table 3

Parameters estimation of logistic regression, odds ratio and its confidence interval of $95 \%$ for infection prevalence by Paracoccidioides brasiliensis (intradermal positive reaction) only for significant variants

\begin{tabular}{lcccc}
\hline Variables & Estimation & Odds ratio & ${ }^{*}$ CI95\% & $p$-value \\
\hline Male gender & 0.768424 & 2.16 & 1.53 to 3.05 & $1.33 \times 10^{-5}$ \\
11 to 29 years & -0.68334 & 0.50 & 0.32 to 0.81 & 0.00372 \\
30 to 49 years & -0.03918 & 0.96 & 0.63 to 1.46 & 0.85085 \\
\hline
\end{tabular}

*CI = Confidence Interval.

intradermal reaction $(p<0.05)$, which was not observed by the logistic regression analysis (Table 3 ).

\section{DISCUSSION}

Paracoccidioidomycosis is the commonest systemic mycosis in Latin America, predominantly affecting individuals who have frequent and close contact with soil. It mainly affects people who are in their most productive stage of life $\mathrm{e}^{2,26}$. Epidemiological surveys have been used to evaluate paracoccidioidomycosis-infection prevalence in Brazil and in other countries in Latin America ${ }^{2,8}$. However, there is an impressive variability in relation to results that can be related to the characteristics of the studied population and to the nature or concentration of the used antigen. It should also take into consideration the chemical compounds and presence of fungus in soil ${ }^{22,34}$.

Classically, paracoccidioidin, a polysaccharide extracted from different strains of $P$. brasiliensis, was the most used antigen for epidemiologic survey studies. More recently, it has been valued using purified antigens in intradermal tests with promising results using the exoantigen gp 43 as paracoccidioidin considered immunodominant and specific component ${ }^{9,11,18,30,31}$. In Brazil, the paracoccidioidin Fava Netto antigen was used in epidemiological surveys, in order to assess the prevalence of PCM infection. Results are not homogeneous, with positivity rates ranging from $2 \%$ among children from different areas of Rio de Janeiro, to $82 \%$ in Cachoeira do Sul ${ }^{8}$. Using the same antigen in Colombia, the prevalence of sensitization to $P$. brasiliensis can reach up to $77 \%$ of the population in certain rural areas $^{4}$, while in Venezuela, the prevalence rates of infection in recent years ranged from $10.2 \%{ }^{33}$ to $19.7 \% \%^{6}$. Argentina has lower prevalence rates of PCM compared to other Latin American countries, a variation being observed in prevalence between $1.6 \%^{16}$ to $10.2 \%^{38}$. Some authors have currently used exoantigen purified gp43 in epidemiological surveys for the delimitation of endemic areas, also noting variable results $(4-45 \%)^{9,11,17,30,31}$. In this study, we found a prevalence of $46.67 \%$ of positive tests in rural areas of Alfenas, MG, Brazil using gp43 paracoccidioidin (Table 1). Similar prevalence $(49.5 \%)$ was also observed in other rural areas (Ibiá, MG) using Fava Netto paracoccidioidin ${ }^{34}$ and in the northwest of Paraná State $(43.0 \%)$ using gp43 paracoccidioidin? .

On the other hand, such antigen may induce cross-reaction in relation to other fungi antigens, e.g., Histoplasma capsulatum, Coccidioides immitis and Sporothrix schenckii ${ }^{13,31,34}$. Simultaneous positive tests for histoplasmin and paracoccidioidin do not necessarily imply a dependence relation among them, taking into consideration the coexistence of fungi in the same area. Meanwhile, this result indicates that it is not possible to state that there is no cross-reaction ${ }^{5,34}$.

Despite the fact that all participants lived in rural areas, only $53.50 \%$ reported to be farm workers (Table 1 ). And $48.28 \%$ had positive intradermal reaction to paracoccidioidin. This was not statistically significant as a risk variant for positive intradermal reaction (Table 2). This could be explained by the fact that they lived in an endemic area and had worked sporadically in farming such as coffee harvest.

Gender differences are one of the most important characteristics of this systemic fungal disease. The incidence and progression of PCM in endemic areas is much higher in adult men than women. In relation to gender and positivity to paracoccidioidin test, we found a significant 
MAGALHÃES, E.M.S.; RIBEIRO, C.F.; DÂMASO, C.S.; COELHO, L.F.L.; SILVA, R.R.; FERREIRA, E.B.; RODRIGUES, M.R.; CAMARGO, Z.P.; VELLOSO, T.R.G. \& MALAQUIAS, L.C.C. - Prevalence of paracoccidioidomycosis infection by intradermal reaction in rural areas in Alfenas, Minas Gerais, Brazil. Rev. Inst. Med. Trop. Sao Paulo, 56(4): 281-5, 2014.

statistical difference among men and women $(p<0.01)$ (Table 2). The multiparametric statistical analysis confirmed these results (Table 3 ). Prevalence of cases in male gender observed in this study is in accordance with numerous other studies ${ }^{5,11,16}$ although recently MARQUES et al $(2013)^{17}$ showed different results.

The differences observed as to the prevalence between men compared to women are not due solely to less exposure or social conditions. Epidemiological data indicate that hormonal factors can have a strong role in the pathogenesis of the disease $\mathrm{e}^{23,28,32}$. Experimental studies in animal tests demonstrate the protective effect of feminine hormones, providing support for the role of $17 \beta$-estradiol in the innate resistance of females to the $\mathrm{PCM}^{29,35}$.

Moreover, the ability of the hormone to modulate the production of cytokines may be associated with improvement of immune response ${ }^{23,32}$. Although women can be infected early, estrogen appears to affect the transition yeast and mycelial increase the secretion of IFN- $\gamma$ and Th1 cell levels and lower levels of IL-10 as demonstrated in experimental models ${ }^{12,15,21,23}$. Furthermore, confirmation of subclinical infection in healthy and asymptomatic, skin tests for delayed hypersensitivity, the paracoccidioidin reveals heterogeneity of response in relation to gender ${ }^{16,32}$. One should take into account that the agent-host relationship factors such as higher or lower environmental exposure, nutritional status, comorbidities, alcoholism and smoking among others, probably interfere with the immune response favoring the progression of infection to disease ${ }^{13,26}$.

Any individual exposed to this fungus is susceptible to infection. However, infection rates increase accordingly with age, as it was observed both in our present study and by SILVA-VERGARA \& MARTINEZ $(1998)^{34}$. This may be more likely related to a higher possibility of sensitization to the fungus, in relation to people living in an endemic area. Prevalence from 30 to 50 years old was $49.56 \%$, the average age being 43 years old.

On the other hand, some life habits may be related to either acquisition of infection or development of the disease. Among other triggering factors, smoking and alcohol addiction have long been associated with the disease. A smoking habit is more likely to influence and/or facilitate the development of this infection due to some possible factors such as change of the mucociliary activity, diminishing of immunity and defects of immunological response of macrophages. In relation to alcohol addiction, it is thought that this drug is a risk cofactor associated with smoking ${ }^{1,7}$. In the present study, $29.33 \%$ of the individuals reported to be addicted to tobacco and $20.67 \%$ to alcohol. Among the tobacco addicted, $52.20 \%$ were positive to a skin test and among alcohol addicted $55.36 \%$ were positive. Meanwhile, such variants were not statistically significant in accordance with the regression analysis (Table 3).

The intradermal test convinced us that it was an important way of identifying if someone was or was not sensitized by the antigen. This makes it easier for patient follow-up, in order to facilitate a future diagnosis and early treatment.

In addition to this, after the intradermal test, it is possible to detect paracoccidioidomycosis endemicity in rural areas. Our results showed a high prevalence of sensitization to $P$. brasiliensis antigen in rural areas, in Alfenas - in Southern MG State. In our view, this data points out the necessity of public health policies to deal with mycosis in this region.

\section{RESUMO}

\section{Prevalência da paracoccidioidomicose por intradermorreação em áreas rurais de Alfenas, Minas Gerais, Brasil}

Este estudo teve como objetivo estimar a prevalência de sensibilização da pele pelo Paracoccidioides brasiliensis em áreas rurais em Alfenas, MG, Brasil, e avaliar os fatores de risco associados à infecção. Foi realizado um estudo transversal de base populacional utilizando testes intradérmicos com paracoccidioidina em 542 indivíduos selecionados por demanda espontânea. Os participantes foram submetidos a uma entrevista através do preenchimento de um formulário de inscrição com os dados epidemiológicos e os testes com a administração intradérmica de $0,1 \mathrm{~mL}$ de paracoccidioidina no antebraço esquerdo. $\mathrm{O}$ teste foi lido $48 \mathrm{~h}$ após a injeção e foi considerado positivo se enduramento era maior ou igual a $5 \mathrm{~mm}$. De 542, 46,67\% participantes foram positivos ao teste de pele. Prevalência aumentou de acordo com o aumento da idade. Houve significância estatística apenas para o sexo masculino. Profissão, alcoolismo e tabagismo não foram significativamente associados com o risco de infecção paracoccidioidomicose. Há relevância da infecção paracoccidioidomicose em áreas rurais, o que sugere mais estudos epidemiológicos e clínicos sobre esta micose no sul do estado de Minas Gerais.

\section{ACKNOWLEDGMENTS}

We would like to thank Nurse Sonia Maria Paz Lima de Souza for helping us with IDR and Dr Adelino Moreira de Carvalho from the School of Medicine at Universidade José do Rosario Vellano, AlfenasMG, with the paper translation and Dr Eva Burger for her critical review of the manuscript.

\section{FINANCIAL SUPPORT}

\section{FAPEMIG APQ-01125-11.}

\section{REFERENCES}

1. Abreu e Silva MA, Salum FG, Fiqueiredo MA, Cherubini K. Important aspects of oral paracoccidioidomycosis: a literature review. Mycoses. 2013;56:189-99.

2. Bellisimo-Rodrigues F, Machado AA, Martins R. Paracoccidioidomycosis epidemiological features of a 1,000-cases series from a hyperendemic area on the southeast of Brazil. Am J Trop Med Hyg. 2011;85:546-50.

3. Cano LE, González A, Lopera D, Naranjo TW, Restrepo A. Pulmonary paracoccidioidomycosis: clinical, immunological and histopathological aspects. In: Irusen EM, editor. Lung diseases-selected state of art reviews. Rijeka: Intech-Europe; 2012. p. 359-91. Available from: http://intechopen.com

4. Cadavid D, Restrepo A. Factors associated with Paracoccidiodes brasiliensis infection among permanent residents of three endemic areas in Colombia. Epidemiol Infect. 1993;111:121-33.

5. Cermeño J, Cermeño J, Godoy G, Hernández I, Orellán Y, Blanco Y, et al. Epidemiological study of paracoccidioidomycosis and histoplasmosis in a suburb of San Félix city, Bolívar State, Venezuela. Invest Clin. 2009;50:2013-20.

6. Cermeño JR, Cermeño JJ, Hernández I, Godoy G, Cermeño JJ, Cabello I, et al. Histoplasmine and paracoccidiodine epidemiological study in Upata, Bolívar State, Venezuela. Trop Med Int Health. 2005;10:216-9. 
MAGALHÃES, E.M.S.; RIBEIRO, C.F.; DÂMASO, C.S.; COELHO, L.F.L.; SILVA, R.R.; FERREIRA, E.B.; RODRIGUES, M.R.; CAMARGO, Z.P.; VELLOSO, T.R.G. \& MALAQUIAS, L.C.C. - Prevalence of paracoccidioidomycosis infection by intradermal reaction in rural areas in Alfenas, Minas Gerais, Brazil. Rev. Inst. Med. Trop. Sao Paulo, 56(4): $281-5,2014$.

7. dos Santos WA, da Silva BM, Passos ED, Zandonade E, Falqueto A. Associação entre tabagismo e paracoccidioidomicose: um estudo de caso-controle no Estado do Espírito Santo, Brasil. Cad Saúde Pública. 2003;19:245-53.

8. Fava SC, Fava Netto C. Epidemiologic surveys of histoplasmin and paracoccidioidin sensitivity in Brazil. Rev Inst Med Trop Sao Paulo. 1998;40:155-64.

9. Fornajeiro N, Maluf MLF, Takahachi G, Svidzinski TIE. Inquérito epidemiológico sobre a paracoccidioidomicose utilizando a gp43 em dois municípios do noroeste do Paraná, Brasil. Rev Soc Bras Med Trop. 2005;38:191-3.

10. Hotez PJ, Bottazzi ME, Franco-Paredes C, Ault SK, Periago MR. The neglected tropical diseases of Latin America and the Caribbean: a review of disease burden and distribution and a road map for control and elimination. PLoS Negl Trop Dis. 2008;2(9):e300.

11. Kalmar EM, Alencar FE, Alves FP, Pang LW, Del Negro GM, Camargo ZP, et al. Paracoccidioidomycosis: an epidemiologic survey in a pediatric population from the Brazilian Amazon using skin tests. Am J Trop Med Hyg. 2004;71:82-6.

12. Karhawi AS, Colombo AL, Salomão R. Production of IFN-gamma is impaired in patients with paracoccidioidomycosis during active disease and is restored after clinical remission. Med Mycol. 2000;38:225-9.

13. Lacaz CS, Porto E, Martins JEC, Heins-Vaccari E, de Melo NT. Paracoccidioidomicose. In: Lacaz CS, Porto E, Martins JEC, Heins-Vaccari EM, Melo NT, editores. Tratado de micologia médica Lacaz. $9^{\text {a }}$ ed. São Paulo: Sarvier; 2002. p. 639-729.

14. Liese B, Rosenberg M, Schratz A. Programmes, partnerships, and governance for elimination and control of neglected tropical diseases. Lancet. 2010;375:67-76.

15. Mamoni RL, Blotta MH. Kinetics of cytokines and chemokines gene expression distinguishes Paracoccidioides brasiliensis infection from disease. Cytokine. 2005;32:20-9

16. Mangiaterra ML, Giusiano GE, Alonso JM, Gorodner JO. Paracoccidioides brasiliensis infection in a subtropical region with important environmental changes. Bull Soc Pathol Exot. 1999;92:173-6.

17. Marques AP, Oliveira SM, Rezende GR, Melo DA, Fernandes-Fitts SM, Pontes ER, et al. Evaluation of Paracoccidioides brasiliensis infection by gp 43 intradermal test in rural settlements in Central-West Brazil. Mycopathologia. 2013;176:41-7.

18. Marques SA. Paracoccidioidomycosis. Clin Dermatol. 2012;30:610-15.

19. Martinez R. Paracoccidioidomycosis: the dimension of the problem of a neglected disease. Rev Soc Bras Med Trop. 2010;43:480

20. Moreira APV. Paracoccidioidomicose: histórico, etiologia, epidemiologia, patogênese, formas clínicas, diagnóstico laboratorial e antígenos. Bol Epidemiol Paul. 2008;5:1124.

21. Oliveira SJ, Mamoni RL, Musatti CC, Papaiordanou PM, Blotta MH. Cytokines and lymphocyte proliferation in juvenile and adult forms of paracoccidioidomycosis: comparison with infected and non-infected controls. Microbes Infect. 2002;4:139-44.

22. Ono MA, Itano EN, Mizuno LT, Mizuno EH, Camargo ZP. Inhibition of Paracoccidioides brasiliensis by pesticides: is this a partial explanation for the difficulty in isolating this fungus from the soil? Med Mycol. 2002;40:493-9.
23. Pinzan CF, Ruas LP, Casabona-Fortunato AS, Carvalho FC, Roque-Barreira MC. Immunological basis for the gender differences in murine Paracoccidioides brasiliensis infection. PLoS One. 2010;5:e10757.

24. R CORE TEAM. The R Project for Statistical Computing. Vienna: R Foundation for Statistical Computing; 2004. p. 20-2 updated on 2011 August 16-18. [cited 2011 Nov 12]. Available from: http://www.R-project.org/

25. Restrepo A, Gómez BL, Tobón A. Paracoccidioidomycosis: Latin America's own funga disorder. Curr Fungal Infect Rep. 2012;6:303-11.

26. Restrepo A, Gonzalez A, Agudelo CA. Paracoccidioidomycosis. In: Kauffman CA, Pappas PG, Sobel JD, Dismukes WE, editors. Essentials of clinicals mycology. $2^{\text {nd }}$ ed. New York: Springer; 2011. p. 367-85.

27. Restrepo A, McEwen JG, Castañeda E. The habitat of Paracoccidioides brasiliensis: how far from solving the riddle? Med Mycol. 2001;39:233-41.

28. Restrepo A, Salazar ME, Cano LE, Stover EP, Feldman D, Stevens DA. Estrogens inhibit mycelium-to-yeast transformation in the fungus Paracoccidioides brasiliensis implications for resistance of females to paracoccidioidomycosis. Infect Immun. $1984 ; 46: 346-53$

29. Salazar ME, Restrepo A, Stevens DA. Inhibition by estrogens of conidium-to-yeast conversion in the fungus Paracoccidioides brasiliensis. Infect Immun. 1988;56:711-3.

30. Saraiva EC, Altemani A, Franco MF, Unterkircher CS, Camargo ZP. Paracoccidioides brasiliensis-gp43 used as paracoccidioidin. J Med Vet Mycol. 1996;34:155-61.

31. Sarti EC, de Oliveira SM, dos Santos LF, de Camargo ZP, Paniago AM. Paracoccidioida infection in HIV patients at an endemic area of paracoccidioidomycosis in Brazil. Mycopathologia. 2012;173:145-9.

32. Shankar J, Restrepo A, Clemons KV, Stevens DA. Hormones and the resistance of women to paracoccidioidomycosis. Clin Microbiol Rev. 2011;24:296-313.

33. Shikanai-Yasuda MA, Telles Filho FQ, Mendes RP, Colombo AL, Moretti ML. Consenso em paracoccidioidomicose. Rev Soc Bras Med Trop. 2006;39:297-310.

34. Silva-Vergara ML, Martinez R. Inquérito epidemiológico com paracoccidioidina e histoplasmina em área agrícola de café em Ibiá, Minas Gerais, Brasil. Rev Iberoam Micol. 1998;15:294-7.

35. Stover EP, Schär G, Clemons KV, Stevens DA, Feldman D. Estradiol-binding proteins from mycelial and yeast-form cultures of Paracoccidioides brasiliensis. Infect Immun. 1986;51:199-203.

36. Teixeira MM, Theodoro RC, de Carvalho MJ, Fernandes L, Paes HC, Hahn RC, et al. Phylogenetic analysis reveals a high level of speciation in the Paracoccidioides genus. Mol Phylogenet Evol. 2009;52:273-83.

37. van Gelderen de Komaid A, Durán E, Borges de Kestelman I. Histoplasmosis and paracoccidioidomycosis in northwestern Argentina. III. Epidemiological survey in Vipos, La Toma, and Choromoro - Trancas, Tucumán, Argentina. Eur J Epidemiol. 1999;15:383-8.

Received: 16 July 2013

Accepted: 28 January 2014 